\title{
Sex-specific differences in lipid and glucose metabolism
}

\author{
Oleg Varlamov ${ }^{1,2}$ *, Cynthia L. Bethea ${ }^{2,3}$ and Charles T. Roberts Jr. ${ }^{1,2,4}$ \\ 1 Division of Diabetes, Obesity, and Metabolism, Oregon National Primate Research Center, Beaverton, OR, USA \\ 2 Division of Developmental and Reproductive Sciences, Oregon National Primate Research Center, Beaverton, OR, USA \\ ${ }^{3}$ Department of Behavioral Neuroscience, Oregon Health and Science University, Portland, OR, USA \\ ${ }^{4}$ Department of Medicine, Oregon Health and Science University, Portland, OR, USA
}

\section{Edited by:}

Janne Lebeck, Danish Diabetes

Academy, Denmark

Reviewed by:

Shinichi Oikawa, Nippon Medical

School, Japan

Zhong Q. Wang, Pennington

Biomedical Research Center, USA

${ }^{*}$ Correspondence:

Oleg Varlamov, Divisions of Diabetes, Obesity, and Metabolism and

Developmental and Reproductive

Sciences, Oregon National Primate

Research Center, 505 NW 185th

Avenue, Beaverton, OR 97006, USA

e-mail:varlamov@ohsu.edu
Energy metabolism in humans is tuned to distinct sex-specific functions that potentially reflect the unique requirements in females for gestation and lactation, whereas male metabolism may represent a default state. These differences are the consequence of the action of sex chromosomes and sex-specific hormones, including estrogens and progesterone in females and androgens in males. In humans, sex-specific specialization is associated with distinct body-fat distribution and energy substrate-utilization patterns; i.e., females store more lipids and have higher whole-body insulin sensitivity than males, while males tend to oxidize more lipids than females. These patterns are influenced by the menstrual phase in females, and by nutritional status and exercise intensity in both sexes. This minireview focuses on sex-specific mechanisms in lipid and glucose metabolism and their regulation by sex hormones, with a primary emphasis on studies in humans and the most relevant pre-clinical model of human physiology, non-human primates.

\section{Keywords: adipose tissue, androgens, estrogens, fatty acid, insulin sensitivity, obesity, sex differences}

\section{INTRODUCTION}

While the role of sex in biology is undisputed, its consideration in research has been the subject of much recent debate. Although initial concerns were raised with the underrepresentation of women in clinical studies $(1,2)$, this issue also applies to pre-clinical research in many fields $(3,4)$. More recently, the National Institutes of Health is considering a proposal to require representation of both sexes in animal as well as cell-based studies $(5,6)$; in the latter instance, the effect of the sex of the source tissue, especially in the case of established cell lines, is not often considered (7). In parallel, a growing number of biomedical research journals are requiring specific clarification of the sex of animals and of the source tissue of cells used in published studies. In this context, it is timely to consider the sex-specific aspects of glucose and lipid metabolism in light of the disruption of these regulatory mechanisms in clinical pathologies such as metabolic syndrome, obesity, and diabetes. It is important to recall the distinction between sex, defined by chromosomal makeup, and gender, which is a social/cultural construct. Thus, in humans, sex differences arise from gene-dosage effects of the $\mathrm{X}$ and $\mathrm{Y}$ chromosomes $(8,9)$, which are elicited to a great extent through the actions of sex hormones. The effect of sex chromosomes themselves on metabolism has been clearly demonstrated by analyses of the four core genotypes mouse model that demonstrated that the sex chromosome complement controls adiposity, feeding behavior, fatty liver, and systemic glucose homeostasis (9), independent of gonadal sex. The mechanisms of sex differences in central nervous system (CNS) control of energy homeostasis in health and disease have been well summarized in several recent reviews (10-14).

\section{SEX-SPECIFIC DIFFERENCES IN FAT DISTRIBUTION}

Women have higher percent body-fat $(15,16)$, less visceral white adipose tissue (V WAT), and more subcutaneous adipose tissue
(SC WAT), both in the abdominal (17-20) and gluteofemoral (21, 22) regions. Various factors responsible for individual variability and sex differences in fat distribution have been described in detail in a recent review (23). Although body-mass index (BMI) is a strong predictor of overall mortality in humans (24), bodyfat distribution is a stronger predictor of metabolic health. For example, low SC WAT is a favorable factor, whereas high V WAT is an unfavorable factor associated with altered lipid and glucose homeostasis (25-27). Furthermore, gluteal-femoral fat may have a protective effect against diabetes and overall mortality (28-30), suggesting that the effective compartmentalization of free fatty acids (FFAs) in low SC WAT may prevent abdominal obesity and associated metabolic disease (31). Regional differences in FFA metabolism do not fully explain sex-specific WAT distribution in humans, although a general trend in regional lipid utilization is consistent with the android and gynoid body types observed in males and females, respectively (25).

\section{SEX-SPECIFIC DIFFERENCES IN LIPID METABOLISM LIPOLYSIS}

Under basal post-absorptive conditions, systemic FFA flux is similar in men and women (32), although upper-body SC WAT is more lipolytically active than lower-body SC WAT in both men and women [Figure 1; $(32,33)$ ]. Non-oxidative FFA clearance through re-esterification, however, is higher in women than in men (34), suggesting that women tend to store, whereas men tend to oxidize, circulating FFAs (35). Men are less sensitive to the antilipolytic effects of insulin; i.e., the release of postprandial FFAs from upperbody SC WAT is less suppressed (more insulin-resistant) in men and FFA release from V WAT is less suppressed in women (32). This pattern of lipolysis is consistent with higher proportion of $\mathrm{V}$ WAT found in men (Figure 1). After a meal, systemic FFA flux is more suppressed by insulin in women (32), suggesting that women 


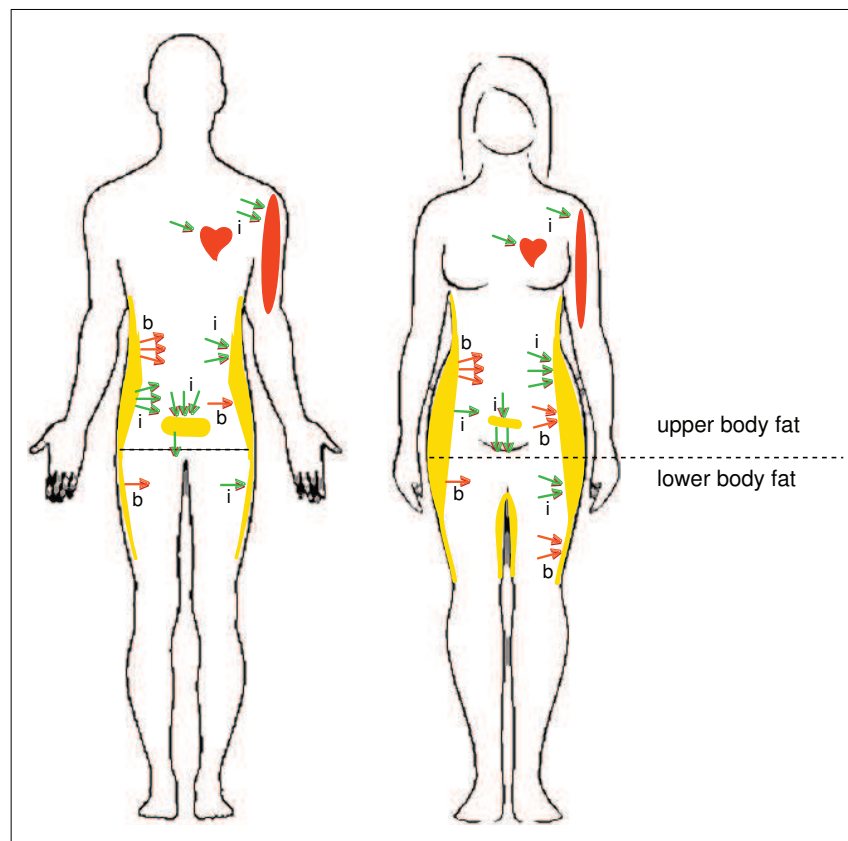

FIGURE 1 | Sex- and depot-specific differences in lipid metabolism in humans. Women have higher percent body-fat and lower muscle mass and oxidize less lipid substrate than men. Women also have less VWAT and more SC WAT, both in the abdominal and gluteofemoral regions, than men Outward arrows indicate basal (b) and insulin-inhibited (i) lipolysis. Inward arrows indicate basal (b) and insulin-stimulated (i) FFA uptake. Under basa post-absorptive conditions, upper-body SC WAT is more lipolytically active than lower-body SC WAT in both men and women (red outward arrows). The release of postprandial FFAs from upper-body SC WAT is less suppressed by insulin in men and FFA release from $V$ WAT is less suppressed in women (green outward arrows). A greater percentage of postprandial FFAs are taken up by upper-body SC WAT in women than in men. Women display higher direct FFA uptake in leg SC WAT than men. Direct FFA uptake is higher in upper SC WAT than in lower SC WAT in men, but not in women. These sex differences in the topography of lipid metabolism may explain higher SC WAT, especially low-body SC WAT, in women compared to men. Higher muscle mass in males is beneficial for more efficient oxidation of FFAs.

may have a higher risk of fat gain. Because the contribution of $\mathrm{V}$ WAT lipolysis to hepatic FFA delivery is greater in women, they are also more susceptible to hepatic insulin resistance $(36,37)$.

\section{FFA UPTAKE AND TRIGLYCERIDE STORAGE}

Although most lipid adsorption in human WAT tissue is mediated via hydrolysis of circulating triglycerides (TG) by lipoprotein lipase (LPL), it is now recognized that direct, LPL-independent FFA uptake may also contribute to lipid storage in humans (38, 39). A greater percentage of meal FFAs is stored (primarily by the LPL-dependent pathway) in upper SC WAT than in lower SC WAT in both men and women, but a greater percentage of dietary FFAs is stored in SC WAT in women than in men, who tend to store FFAs in VWAT [Figure 1; $(35,40)$ ]. Interestingly, testosterone treatment increases the percentage of FFAs stored in SC WAT and decreases FFA storage in V WAT in middle-aged men (41). Basal FFA uptake and expression levels of FFA transporters are higher in upper SC WAT than in lower SC WAT in men, but not in women $(38,39)$.
Women, however, display higher FFA uptake in leg SC WAT, which correlates with greater postprandial WAT LPL activity in women [Figure 1; (42)]. Furthermore, women have the highest rate of TG synthesis in their SC WAT compared to their visceral or any WAT depot in men (43). The menstrual cycle has no apparent effect on FFA tissue uptake in healthy women, consistent with studies in female non-human primates (NHPs) $(35,44)$.

\section{SEX-SPECIFIC DIFFERENCES IN GLUCOSE METABOLISM AND INSULIN ACTION}

Glucose metabolism in both sexes is highly responsive to physiological and nutritional states and physical fitness (45). During exercise, women oxidize more lipids and less carbohydrates, deplete less muscle glycogen, and exhibit lower hepatic glucose production $(46,47)$. At high altitude, women are able to attenuate the use of carbohydrates (48). This preferential substrate selection is attributed to estrogens (49). The potential mechanisms responsible for sex-specific metabolic responses to exercise include lower sympathetic nerve activity (50) and a greater type I and type II muscle fiber density (51) in women. Despite having a lower percentage of fat mass, the prevalence of type- 2 diabetes and insulin resistance is higher in men (52-54). These differences are explained by higher whole-body insulin sensitivity in women (55-57). The human data are consistent with rodent studies that demonstrated greater insulin sensitivity and greater resistance to a high-fat diet (HFD) in females (58-61). The majority of human studies showed that glucose effectiveness and glucose appearance rates (62) are also higher in women (63-66).

The mechanisms responsible for sex differences in insulin sensitivity are not understood. One study reported no differences in insulin secretion between young males and young females (64), whereas others showed that females have higher first-phase insulin secretion than males (65). Sex differences in insulin signaling are tissue-specific, but have been primarily studied in rodent models (67). Kahn and colleagues reported that, in rodents, female WAT had a greater response to insulin and a greater increase in Akt and extracellular signal-related kinase (ERK) phosphorylation and lipogenesis than male WAT (61). Castration increased the insulin responsiveness of male WAT, while ovariectomy decreased insulin responsiveness of female WAT (61). Our studies in NHPs, however, suggest that, in contrast to rodents, testosterone promotes insulin-stimulated Akt phosphorylation and stimulates lipogenesis in WAT of castrated males (68). Greater rates of insulinstimulated glucose uptake in female skeletal muscle and WAT correlate with higher expression levels of muscle mRNAs encoding glucose transporter-4 (Glut4) and metabolic enzymes (69).

\section{SEX HORMONES AND METABOLISM}

\section{ESTROGENS, PROGESTERONE, AND MENSTRUAL CYCLE}

The use of oral steroidal contraceptives is associated with a reduction in insulin sensitivity and low estrogen levels (70), suggesting that estrogens may protect females against insulin resistance. Consistent with this idea, studies in estrogen-deficient aromataseknockout (ArKO) and ovariectomized wild-type mice showed that estrogen replacement can protect female mice against hepatic steatosis and improve mitochondrial $\beta$-oxidation (71) and insulin sensitivity $(61,72)$. The molecular mechanisms responsible for 
estrogen-mediated improvement in lipid-induced insulin resistance are tissue and pathway-specific and estrogen's effects on various signal transduction and metabolic pathways in adipocytes, myocytes, and hepatocytes have been described in detail in a recent review (73).

Many anti-obesity effects of estrogens in mice are mediated by central mechanisms. Important regulators of metabolism have receptors in the CNS that mediate overall energy expenditure, food intake, glucose, and homeostasis (74). However, little is known about sex differences in CNS regulation of metabolism and most research has focused on estrogen action (75). The majority of estrogen's anorexic action in the hypothalamus is mediated by estrogen receptor- $\alpha(\mathrm{ER} \alpha)$, and not estrogen receptor- $\beta$ (ER $\beta)$ (76), although one study contested this notion (77). Diminished $\mathrm{ER} \alpha$ activity is associated with obesity in both sexes. Estrogendeficient androgen receptor (AR) knockout and ER $\alpha$ knockout male and female mice are obese and have decreased energy expenditure (78-80).

In addition to central mechanisms, estrogens can also directly suppress TG synthesis by reducing lipogenesis in the liver and increasing lipolysis in adipocytes (81-83). Estrogens potentiate lipid accumulation in SC WAT in males and females $(84,85)$, promote FFA $\beta$-oxidation, and reduce TG storage by stimulating the expression of peroxisome proliferation activator receptor-delta (PPAR $\delta$ ) and by activating AMP-activated protein kinase [AMPK; (81)]. In pancreas, estrogens exert protective effects on $\beta$-cell function by reducing amyloid formation in ovariectomized females (86) and obese males (87), and decrease $\beta$-cell injury induced by streptozotocin $(\mathrm{STZ})$ in both sexes $(88,89)$. Interestingly, men lacking estrogen production or signaling because of mutations in the genes encoding aromatase or $\mathrm{ER} \alpha$ are insulin-resistant and glucose-intolerant $(90,91)$, suggesting that estrogens may also regulate energy homeostasis in males. Although the beneficial effects of estrogens on whole-body glucose metabolism and insulin sensitivity have been demonstrated in several rodent models $(73,92)$, sex-specific effects in humans remain to be further elucidated.

Glucose metabolism is also affected by the menstrual phase, when the energy demand is high, which can be explained by the suppressive effect of estrogens and progesterone on gluconeogenesis (93). Estrogens promote insulin sensitivity, whereas progesterone promotes insulin resistance by antagonizing the positive effect of estrogens on contraction-stimulated glucose uptake (94) and increasing the activity of the $\beta$-oxidation pathway in skeletal muscle during exercise $(95,96)$. Glucose metabolism and exercise performance are influenced by the menstrual cycle phase in that glucose appearance and disappearance rates are higher during the follicular phase (high estrogen-to-progesterone ratio) compared to the luteal phase (high progesterone-to-estrogen ratio) (97). Muscle glycogen utilization depends on FFA availability in that there is an inverse correlation between FFA concentration and muscle glycogen use during exercise. The opposing actions of estrogens and progesterone on glycogen utilization may be mediated by their impact on FFA availability (98). Thus, glucose and lipid metabolism depends on the menstrual cycle phase, which determines the progesterone-to-estrogen ratio, and nutritional and exercise status.

\section{ANDROGENS}

A significant portion of the world population suffers from various forms of metabolic abnormalities related to androgen imbalance, including hypoandrogenism in men (99-105) and hyperandrogenism in women $(99,106)$. Androgen deficiency in men is associated with insulin resistance and obesity, and treatment of hypogonadal men with testosterone improves insulin sensitivity and reduces fat content (99-105). In contrast, the androgen excess observed in women with polycystic ovary syndrome (PCOS) is associated with insulin resistance and obesity $(99,106)$.

Sex-dependent actions of androgens in WAT may explain differences in body-fat distribution (107) and insulin sensitivity in males and females $(52,54-56,61)$. Aromatization of testosterone to $17 \beta$-estradiol is important for energy homeostasis, and an increased androgen-to-estrogen ratio promotes visceral obesity in males $(108,109)$. Men with genetic androgen resistance due to decreased AR expression develop visceral obesity (110), and AR knockout mice demonstrate higher visceral adiposity and insulin resistance $(111,112)$, suggesting that androgens may suppress WAT mass both in humans and rodents. Although human studies consistently demonstrate a positive correlation between hypogonadism, increased body-fat, and insulin resistance (99-105, 113, 114), it is unknown whether these changes represent direct effects of androgen imbalance on target tissues or secondary effects of aging or changes in lifestyle on whole-body metabolism and body composition.

For example, testosterone promotes the commitment of pluoropotent mesenchymal stem cells to the myogenic lineage (115), which may indirectly improve energy expenditure and accelerate fat mass loss, contributing to improved insulin sensitivity in testosterone-supplemented males. Testosterone increases the expression of the transcription factor PGC1 $\alpha$ in skeletal muscle (116), stimulating mitochondrial biogenesis, substrate oxidation, and muscle insulin sensitivity. Lower levels of PGC1 $\alpha$ are found in insulin-resistant type-2 diabetic patients (117). In rodents, testosterone exerts gender-specific protective effects against STZinduced apoptosis of male $\beta$-cells $(118,119)$. Interestingly, androgen administration to normally STZ-resistant female rats make them highly susceptible to $\beta$-cell death (88). Thus, in rodents testosterone is involved in a gender-specific regulation of $\beta$-cell number, playing a protective antidiabetic role in males, but can override the protective role of estrogens in females, illustrating the importance of the androgen/estrogen ratio in $\beta$-cell survival in females.

\section{SEX-SPECIFIC EFFECTS IN NHPS}

Consistent with human studies, female rhesus macaques exhibit significantly higher levels of insulin-stimulated glucose disposal than males (120) and estrogens can improve glucose regulation in female macaques (121). In contrast to estrogen effects, adult female rhesus macaques exposed to androgens developed insulin resistance, although this effect was only apparent in animals consuming a HFD (44). Studies in prenatally androgenized monkeys further demonstrated that androgens disrupt insulin sensitivity and glucoregulation in female offspring $(122,123)$. These findings are consistent with the idea that exposure of females to androgens may trigger a metabolic reprograming toward a male-like phenotype. 
Androgen effects in adult female NHPs are menstrual cycledependent, in that V WAT lipolysis and hormone-sensitive lipase (HSL) expression were upregulated during the luteal phase compared with the early follicular phase of the ovarian cycle, while hyperandrogenemia attenuated lipolysis and HSL expression during the luteal phase but not during menses (44). Insulin sensitivity of FFA uptake in WAT was also differentially affected by testosterone in a menstrual cycle-dependent manner (44). Collectively, these findings may explain the predisposition of women with PCOS to WAT dysfunction and obesity $(99,106)$. Androgen supplementation studies in adult male rhesus macaques suggest that androgens do not control whole-body insulin sensitivity, at least under conditions of a low-fat (chow) diet $(68,124)$, but a lack of testosterone can have a negative impact on WAT biogenesis and function (68). Prenatally androgenized male rhesus macaques, however, develop insulin resistance, suggesting that early exposure to androgens may cause fetal reprograming of male metabolic tissues (125). Interestingly, testosterone stimulates WAT lipogenic gene expression in both males and females $(44,68)$, suggesting that androgens can facilitate maturation of WAT in both sexes.

\section{CONCLUSION}

Overall, female lipid metabolism functions to store more fat in SC WAT, with a higher proportion of lipids deposited in lower body-fat, while men store more lipids in V WAT than in SC WAT and oxidize dietary FFAs more readily than women. These differences presumably reflect the opposite sex-specific specialization in energy utilization, with women having the unique burden of gestation and lactation. Higher insulin sensitivity and lower muscle mass observed in women is more beneficial for energy storage in WAT and less beneficial for its oxidation. Furthermore, more efficient insulin inhibition of lipolysis facilitates greater TG retention in female WAT than in male WAT. Estrogens and androgens exert beneficial metabolic effects by lowering body-fat and improving insulin sensitivity in females and males, respectively, although the role of androgens in regulating insulin action in humans, especially under conditions of different diets, remains controversial. The use of NHP models may help separate the direct effects of sex hormones on metabolic tissues from indirect effects, such as the differences in lifestyle, diet, and prior medical history observed in human patients.

\section{ACKNOWLEDGMENTS}

This work was supported by NIH grants R21 AG047543 (Oleg Varlamov), R01 MH86542 (Cynthia L. Bethea), P50 HD071836 (Charles T. Roberts Jr.), and P51 OD011092 for operation of the Oregon National Primate Research Center.

\section{REFERENCES}

1. I.O.M. Sex Differences and Implications for Translational Neuroscience Research: Workshop Summary. Washington, DC: The National Academies Press (2011).

2. I.O.M. Sex-Specific Reporting of Scientific Research: A Workshop Summary. Washington, DC: The National Academies Press (2012).

3. Beery AK, Zucker I. Sex bias in neuroscience and biomedical research. Neurosci Biobehav Rev (2011) 35:565-72. doi:10.1016/j.neubiorev.2010.07.002

4. Woodruff TK, Kibbe MR, Paller AS, Turek FW, Woolley CS. Commentary: "Leaning in" to support sex differences in basic science and clinical research. Endocrinology (2014) 155:1181-3. doi:10.1210/en.2014-1068
5. Clayton JA, Collins FS. Policy: NIH to balance sex in cell and animal studies. Nature (2014) 509:282-3. doi:10.1038/509282a

6. Danska JS. Sex matters for mechanism. Sci Transl Med (2014) 6:258fs240. doi:10.1126/scitranslmed.3009859

7. Fuller CM, Insel PA. I don't know the question, but sex is definitely the answer! Focus on "In pursuit of scientific excellence: sex matters" and "Do you know the sex of your cells? Am J Physiol Cell Physiol (2014) 306:C1-2. doi:10.1152/ajpcell.00342.2013

8. Chen X, McClusky R, Itoh Y, Reue K, Arnold AP. X and Y chromosome complement influence adiposity and metabolism in mice. Endocrinology (2013) 154:1092-104. doi:10.1210/en.2012-2098

9. Link JC, Chen X, Arnold AP, Reue K. Metabolic impact of sex chromosomes. Adipocyte (2013) 2:74-9. doi:10.4161/adip.23320

10. Shi H, Strader AD, Sorrell JE, Chambers JB, Woods SC, Seeley RJ. Sexually different actions of leptin in proopiomelanocortin neurons to regulate glucose homeostasis. Am J Physiol Endocrinol Metab (2008) 294:E630-9. doi:10.1152/ajpendo.00704.2007

11. Lovejoy JC, Sainsbury A. Sex differences in obesity and the regulation of energy homeostasis. Obes Rev (2009) 10:154-67. doi:10.1111/j.1467-789X. 2008.00529.x

12. Shi H, Clegg DJ. Sex differences in the regulation of body weight. Physiol Behav (2009) 97:199-204. doi:10.1016/j.physbeh.2009.02.017

13. Arnetz L, Ekberg NR, Alvarsson M. Sex differences in type 2 diabetes: focus on disease course and outcomes. Diabetes Metab Syndr Obes (2014) 7:409-20. doi:10.2147/DMSO.S51301

14. Henderson GC. Sexual dimorphism in the effects of exercise on metabolism of lipids to support resting metabolism. Front Endocrinol (Lausanne) (2014) 5:162. doi:10.3389/fendo.2014.00162

15. Womersley J. A comparison of the skinfold method with extent of 'overweight' and various weight-height relationships in the assessment of obesity. Br J Nutr (1977) 38:271-84. doi:10.1079/BJN19770088

16. Jackson AS, Stanforth PR, Gagnon J, Rankinen T, Leon AS, Rao DC, et al. The effect of sex, age and race on estimating percentage body fat from body mass index: the Heritage Family Study. Int J Obes Relat Metab Disord (2002) 26:789-96. doi:10.1038/sj.ijo.0802006

17. Schreiner PJ, Terry JG, Evans GW, Hinson WH, Crouse JR III, Heiss G. Sex-specific associations of magnetic resonance imaging-derived intraabdominal and subcutaneous fat areas with conventional anthropometric indices. The Atherosclerosis Risk in Communities Study. Am JEpidemiol (1996) 144:335-45. doi:10.1093/oxfordjournals.aje.a008934

18. Despres JP, Couillard C, Gagnon J, Bergeron J, Leon AS, Rao DC, et al. Race, visceral adipose tissue, plasma lipids, and lipoprotein lipase activity in men and women: the health, risk factors, exercise training, and genetics (HERITAGE) family study. Arterioscler Thromb Vasc Biol (2000) 20:1932-8. doi:10.1161/01.ATV.20.8.1932

19. Demerath EW, Sun SS, Rogers N, Lee M, Reed D, Choh AC, et al. Anatomical patterning of visceral adipose tissue: race, sex, and age variation. Obesity (Silver Spring) (2007) 15:2984-93. doi:10.1038/oby.2007.356

20. Camhi SM, Bray GA, Bouchard C, Greenway FL, Johnson WD, Newton RL, et al. The relationship of waist circumference and BMI to visceral, subcutaneous, and total body fat: sex and race differences. Obesity (Silver Spring) (2011) 19:402-8. doi:10.1038/oby.2010.248

21. Goodpaster BH, Krishnaswami S, Harris TB, Katsiaras A, Kritchevsky SB, Simonsick EM, et al. Obesity, regional body fat distribution, and the metabolic syndrome in older men and women. Arch Intern Med (2005) 165:777-83. doi:10.1001/archinte.165.7.777

22. Yim JE, Heshka S, Albu JB, Heymsfield S, Gallagher D. Femoral-gluteal subcutaneous and intermuscular adipose tissues have independent and opposing relationships with CVD risk. J Appl Physiol (1985) (2008) 104:700-7. doi:10.1152/japplphysiol.01035.2007

23. Karastergiou K, Smith SR, Greenberg AS, Fried SK. Sex differences in human adipose tissues - the biology of pear shape. Biol Sex Differ (2012) 3:13. doi:10.1186/2042-6410-3-13

24. Whitlock G, Lewington S, Sherliker P, Clarke R, Emberson J, Halsey J, et al. Body-mass index and cause-specific mortality in 900000 adults: collaborative analyses of 57 prospective studies. Lancet (2009) 373:1083-96. doi:10.1016/S0140-6736(09)60318-4 
25. Vague J. The degree of masculine differentiation of obesities: a factor determining predisposition to diabetes, atherosclerosis, gout, and uric calculous disease. Am J Clin Nutr (1956) 4:20-34.

26. Snijder MB, Visser M, Dekker JM, Goodpaster BH, Harris TB, Kritchevsky $\mathrm{SB}$, et al. Low subcutaneous thigh fat is a risk factor for unfavourable glucose and lipid levels, independently of high abdominal fat. The Health ABC Study. Diabetologia (2005) 48:301-8. doi:10.1007/s00125-004-1637-7

27. Bluher M. The distinction of metabolically 'healthy' from 'unhealthy' obese individuals. Curr Opin Lipidol (2010) 21:38-43. doi:10.1097/MOL. 0b013e3283346ccc

28. Folsom AR, Kaye SA, Sellers TA, Hong CP, Cerhan JR, Potter JD, et al. Body fat distribution and 5-year risk of death in older women. JAMA (1993) 269:483-7. doi:10.1001/jama.269.4.483

29. Carey VJ, Walters EE, Colditz GA, Solomon CG, Willett WC, Rosner BA, et al. Body fat distribution and risk of non-insulin-dependent diabetes mellitus in women. The Nurses' Health Study. Am J Epidemiol (1997) 145:614-9. doi:10.1093/oxfordjournals.aje.a009158

30. Pischon T, Boeing H, Hoffmann K, Bergmann M, Schulze MB, Overvad K, et al. General and abdominal adiposity and risk of death in Europe. $N$ Engl J Med (2008) 359:2105-20. doi:10.1056/NEJMoa0801891

31. Hernandez TL, Kittelson JM, Law CK, Ketch LL, Stob NR, Lindstrom RC, et al. Fat redistribution following suction lipectomy: defense of body fat and patterns of restoration. Obesity (Silver Spring) (2011) 19:1388-95. doi:10.1038/ oby. 2011.64

32. Jensen MD. Gender differences in regional fatty acid metabolism before and after meal ingestion. J Clin Invest (1995) 96:2297-303. doi:10.1172/JCI118285

33. Martin ML, Jensen MD. Effects of body fat distribution on regional lipolysis in obesity. J Clin Invest (1991) 88:609-13. doi:10.1172/JCI115345

34. Nielsen S, Guo Z, Albu JB, Klein S, O’Brien PC, Jensen MD. Energy expenditure, sex, and endogenous fuel availability in humans. J Clin Invest (2003) 111:981-8. doi:10.1172/JCI16253

35. Uranga AP, Levine J, Jensen M. Isotope tracer measures of meal fatty acid metabolism: reproducibility and effects of the menstrual cycle. Am J Physiol Endocrinol Metab (2005) 288:E547-55. doi:10.1152/ajpendo.00340.2004

36. Miyazaki Y, Glass L, Triplitt C, Wajcberg E, Mandarino LJ, Defronzo RA. Abdominal fat distribution and peripheral and hepatic insulin resistance in type 2 diabetes mellitus. Am J Physiol Endocrinol Metab (2002) 283:E1135-43. doi:10.1152/ajpendo.00327.2001

37. Nielsen S, Guo Z, Johnson CM, Hensrud DD, Jensen MD. Splanchnic lipolysis in human obesity. J Clin Invest (2004) 113:1582-8. doi:10.1172/JCI21047

38. Bickerton AS, Roberts R, Fielding BA, Hodson L, Blaak EE, Wagenmakers AJ et al. Preferential uptake of dietary fatty acids in adipose tissue and muscle in the postprandial period. Diabetes (2007) 56:168-76. doi:10.2337/db06-0822

39. Shadid S, Koutsari C, Jensen MD. Direct free fatty acid uptake into human adipocytes in vivo: relation to body fat distribution. Diabetes (2007) 56:1369-75. doi:10.2337/db06-1680

40. Romanski SA, Nelson RM, Jensen MD. Meal fatty acid uptake in adipose tissue: gender effects in nonobese humans. Am J Physiol Endocrinol Metab (2000) 279:E455-62.

41. Marin P, Lonn L, Andersson B, Oden B, Olbe L, Bengtsson BA, et al. Assimilation of triglycerides in subcutaneous and intraabdominal adipose tissues in vivo in men: effects of testosterone. J Clin Endocrinol Metab (1996) 81:1018-22. doi:10.1210/jcem.81.3.8772568

42. Votruba SB, Jensen MD. Sex-specific differences in leg fat uptake are revealed with a high-fat meal. Am J Physiol Endocrinol Metab (2006) 291:E1115-23. doi:10.1152/ajpendo.00196.2006

43. Edens NK, Fried SK, Kral JG, Hirsch J, Leibel RL. In vitro lipid synthesis in human adipose tissue from three abdominal sites. Am J Physiol (1993) 265:E374-9.

44. Varlamov O, Chu MP, McGee WK, Cameron JL, O’Rourke RW, Meyer KA, et al. Ovarian cycle-specific regulation of adipose tissue lipid storage by testosterone in female nonhuman primates. Endocrinology (2013) 154:4126-35. doi:10.1210/en.2013-1428

45. Tarnopolsky MA, Ruby BC. Sex differences in carbohydrate metabolism. Curr Opin Clin Nutr Metab Care (2001) 4:521-6. doi:10.1097/00075197200111000-00010

46. McKenzie S, Phillips SM, Carter SL, Lowther S, Gibala MJ, Tarnopolsky MA. Endurance exercise training attenuates leucine oxidation and BCOAD activation during exercise in humans. Am J Physiol Endocrinol Metab (2000) 278:E580-7.

47. Carter SL, Rennie C, Tarnopolsky MA. Substrate utilization during endurance exercise in men and women after endurance training. Am J Physiol Endocrinol Metab (2001) 280:E898-907.

48. Braun B, Mawson JT, Muza SR, Dominick SB, Brooks GA, Horning MA, et al. Women at altitude: carbohydrate utilization during exercise at 4,300 m. J Appl Physiol (1985) (2000) 88:246-56.

49. Carter S, McKenzie S, Mourtzakis M, Mahoney DJ, Tarnopolsky MA. Shortterm 17beta-estradiol decreases glucose R(a) but not whole body metabolism during endurance exercise. J Appl Physiol (1985) (2001) 90:139-46.

50. Jones PP, Snitker S, Skinner JS, Ravussin E. Gender differences in muscle sympathetic nerve activity: effect of body fat distribution. Am J Physiol (1996) 270:E363-6.

51. Simoneau JA, Bouchard C. Human variation in skeletal muscle fiber-type proportion and enzyme activities. Am J Physiol (1989) 257:E567-72.

52. Frias JP, Macaraeg GB, Ofrecio J, Yu JG, Olefsky JM, Kruszynska YT. Decreased susceptibility to fatty acid-induced peripheral tissue insulin resistance in women. Diabetes (2001) 50:1344-50. doi:10.2337/diabetes.50.6. 1344

53. Kuhl J, Hilding A, Ostenson CG, Grill V, Efendic S, Bavenholm P. Characterisation of subjects with early abnormalities of glucose tolerance in the Stockholm diabetes prevention programme: the impact of sex and type 2 diabetes heredity. Diabetologia (2005) 48:35-40. doi:10.1007/s00125-004-1614-1

54. Soeters MR, Sauerwein HP, Groener JE, Aerts JM, Ackermans MT, Glatz JF, et al. Gender-related differences in the metabolic response to fasting. J Clin Endocrinol Metab (2007) 92:3646-52. doi:10.1210/jc.2007-0552

55. Boyns DR, Crossley JN, Abrams ME, Jarrett RJ, Keen H. Oral glucose tolerance and related factors in a normal population sample. I. Blood sugar, plasma insulin, glyceride, and cholesterol measurements and the effects of age and sex. Br Med J (1969) 1:595-8. doi:10.1136/bmj.1.5644.595

56. Yki-Jarvinen H. Sex and insulin sensitivity. Metabolism (1984) 33:1011-5. doi:10.1016/0026-0495(84)90229-4

57. Nuutila P, Knuuti MJ, Maki M, Laine H, Ruotsalainen U, Teras M, et al. Gender and insulin sensitivity in the heart and in skeletal muscles. Studies using positron emission tomography. Diabetes (1995) 44:31-6. doi:10.2337/ diab.44.1.31

58. Zierath JR, Houseknecht KL, Gnudi L, Kahn BB. High-fat feeding impairs insulin-stimulated GLUT4 recruitment via an early insulin-signaling defect. Diabetes (1997) 46:215-23. doi:10.2337/diabetes.46.2.215

59. Corsetti JP, Sparks JD, Peterson RG, Smith RL, Sparks CE. Effect of dietary fat on the development of non-insulin dependent diabetes mellitus in obese Zucker diabetic fatty male and female rats. Atherosclerosis (2000) 148:231-41. doi:10.1016/S0021-9150(99)00265-8

60. Trevaskis JL, Meyer EA, Galgani JE, Butler AA. Counterintuitive effects of double-heterozygous null melanocortin-4 receptor and leptin genes on dietinduced obesity and insulin resistance in C57BL/6J mice. Endocrinology (2008) 149:174-84. doi:10.1210/en.2007-0868

61. Macotela Y, Boucher J, Tran TT, Kahn CR. Sex and depot differences in adipocyte insulin sensitivity and glucose metabolism. Diabetes (2009) 58:803-12. doi:10.2337/db08-1054

62. Best JD, Kahn SE, Ader M, Watanabe RM, Ni TC, Bergman RN. Role of glucose effectiveness in the determination of glucose tolerance. Diabetes Care (1996) 19:1018-30. doi:10.2337/diacare.19.9.1018

63. Hale PJ, Wright JV, Nattrass M. Differences in insulin sensitivity between normal men and women. Metabolism (1985) 34:1133-8. doi:10.1016/00260495(85)90159-3

64. Basu R, Dalla Man C, Campioni M, Basu A, Klee G, Toffolo G, et al. Effects of age and sex on postprandial glucose metabolism: differences in glucose turnover, insulin secretion, insulin action, and hepatic insulin extraction. Diabetes (2006) 55:2001-14. doi:10.2337/db05-1692

65. Flanagan DE, Holt RI, Owens PC, Cockington RJ, Moore VM, Robinson JS, et al. Gender differences in the insulin-like growth factor axis response to a glucose load. Acta Physiol (Oxf) (2006) 187:371-8. doi:10.1111/j.1748-1716. 2006.01581.x

66. Bock G, Dalla Man C, Campioni M, Chittilapilly E, Basu R, Toffolo G, et al. Effects of nonglucose nutrients on insulin secretion and action in people with pre-diabetes. Diabetes (2007) 56:1113-9. doi:10.2337/db06-1272 
67. Mayes JS, Watson GH. Direct effects of sex steroid hormones on adipose tissues and obesity. Obes Rev (2004) 5:197-216. doi:10.1111/j.1467-789X.2004. 00152.x

68. Varlamov O, White AE, Carroll JM, Bethea CL, Reddy A, Slayden O, et al. Androgen effects on adipose tissue architecture and function in nonhuman primates. Endocrinology (2012) 153:3100-10. doi:10.1210/en.2011-2111

69. Rune A, Salehzadeh F, Szekeres F, Kuhn I, Osler ME, Al-Khalili L. Evidence against a sexual dimorphism in glucose and fatty acid metabolism in skeletal muscle cultures from age-matched men and post-menopausal women. Acta Physiol (Oxf) (2009) 197:207-15. doi:10.1111/j.1748-1716.2009.02010.x

70. Perseghin G, Scifo P, Pagliato E, Battezzati A, Benedini S, Soldini L, et al. Gender factors affect fatty acids-induced insulin resistance in nonobese humans: effects of oral steroidal contraception. J Clin Endocrinol Metab (2001) 86:3188-96. doi:10.1210/jcem.86.7.7666

71. Nemoto Y, Toda K, Ono M, Fujikawa-Adachi K, Saibara T, Onishi S, et al. Altered expression of fatty acid-metabolizing enzymes in aromatase-deficient mice. J Clin Invest (2000) 105:1819-25. doi:10.1172/JCI9575

72. Camporez JP, Jornayvaz FR, Lee HY, Kanda S, Guigni BA, Kahn M, et al. Cellular mechanism by which estradiol protects female ovariectomized mice from highfat diet-induced hepatic and muscle insulin resistance. Endocrinology (2013) 154:1021-8. doi:10.1210/en.2012-1989

73. Jelenik T, Roden M. How estrogens prevent from lipid-induced insulin resistance. Endocrinology (2013) 154:989-92. doi:10.1210/en.2013-1112

74. Xu Y, Nedungadi TP, Zhu L, Sobhani N, Irani BG, Davis KE, et al. Distinct hypothalamic neurons mediate estrogenic effects on energy homeostasis and reproduction. Cell Metab (2011) 14:453-65. doi:10.1016/j.cmet.2011.08.009

75. Clegg DJ. Minireview: the year in review of estrogen regulation of metabolism. Mol Endocrinol (2012) 26:1957-60. doi:10.1210/me.2012-1284

76. Geary N, Asarian L, Korach KS, Pfaff DW, Ogawa S. Deficits in E2-dependent control of feeding, weight gain, and cholecystokinin satiation in ER-alpha null mice. Endocrinology (2001) 142:4751-7. doi:10.1210/endo.142.11.8504

77. Liang YQ, Akishita M, Kim S, Ako J, Hashimoto M, Iijima K, et al. Estrogen receptor beta is involved in the anorectic action of estrogen. Int J Obes Relat Metab Disord (2002) 26:1103-9. doi:10.1038/sj.ijo.0802054

78. Heine PA, Taylor JA, Iwamoto GA, Lubahn DB, Cooke PS. Increased adipose tissue in male and female estrogen receptor-alpha knockout mice. Proc Natl Acad Sci U S A (2000) 97:12729-34. doi:10.1073/pnas.97.23.12729

79. Jones ME, Thorburn AW, Britt KL, Hewitt KN, Wreford NG, Proietto J, et al. Aromatase-deficient (ArKO) mice have a phenotype of increased adiposity. Proc Natl Acad Sci U S A (2000) 97:12735-40. doi:10.1073/pnas.97.23.12735

80. Ribas V, Nguyen MT, Henstridge DC, Nguyen AK, Beaven SW, Watt MJ, et al. Impaired oxidative metabolism and inflammation are associated with insulin resistance in ERalpha-deficient mice. Am J Physiol Endocrinol Metab (2010) 298:E304-19. doi:10.1152/ajpendo.00504.2009

81. D'Eon TM, Souza SC, Aronovitz M, Obin MS, Fried SK, Greenberg AS. Estrogen regulation of adiposity and fuel partitioning. Evidence of genomic and nongenomic regulation of lipogenic and oxidative pathways. J Biol Chem (2005) 280:35983-91. doi:10.1074/jbc.M507339200

82. Gao H, Bryzgalova G, Hedman E, Khan A, Efendic S, Gustafsson JA, et al. Longterm administration of estradiol decreases expression of hepatic lipogenic genes and improves insulin sensitivity in ob/ob mice: a possible mechanism is through direct regulation of signal transducer and activator of transcription 3. Mol Endocrinol (2006) 20:1287-99. doi:10.1210/me.2006-0012

83. Bryzgalova G, Lundholm L, Portwood N, Gustafsson JA, Khan A, Efendic $\mathrm{S}$, et al. Mechanisms of antidiabetogenic and body weight-lowering effects of estrogen in high-fat diet-fed mice. Am J Physiol Endocrinol Metab (2008) 295:E904-12. doi:10.1152/ajpendo.90248.2008

84. Cooke PS, Naaz A. Role of estrogens in adipocyte development and function. Exp Biol Med (Maywood) (2004) 229:1127-35.

85. Clegg DJ, Brown LM, Woods SC, Benoit SC. Gonadal hormones determine sensitivity to central leptin and insulin. Diabetes (2006) 55:978-87. doi:10.2337/diabetes.55.04.06.db05-1339

86. Kahn SE, Andrikopoulos S, Verchere CB, Wang F, Hull RL, Vidal J. Oophorectomy promotes islet amyloid formation in a transgenic mouse model of Type II diabetes. Diabetologia (2000) 43:1309-12. doi:10.1007/s001250051527

87. Geisler JG, Zawalich W, Zawalich K, Lakey JR, Stukenbrok H, Milici AJ, et al. Estrogen can prevent or reverse obesity and diabetes in mice expressing human islet amyloid polypeptide. Diabetes (2002) 51:2158-69. doi:10.2337/diabetes. 51.7.2158

88. Paik SG, Michelis MA, Kim YT, Shin S. Induction of insulin-dependent diabetes by streptozotocin. Inhibition by estrogens and potentiation by androgens. Diabetes (1982) 31:724-9. doi:10.2337/diab.31.8.724

89. Le May C, Chu K, Hu M, Ortega CS, Simpson ER, Korach KS, et al. Estrogens protect pancreatic beta-cells from apoptosis and prevent insulin-deficient diabetes mellitus in mice. Proc Natl Acad Sci U S A (2006) 103:9232-7. doi:10.1073/pnas.0602956103

90. Smith EP, Boyd J, Frank GR, Takahashi H, Cohen RM, Specker B, et al. Estrogen resistance caused by a mutation in the estrogen-receptor gene in a man. NEngl J Med (1994) 331:1056-61. doi:10.1056/NEJM199410203311604

91. Morishima A, Grumbach MM, Simpson ER, Fisher C, Qin K. Aromatase deficiency in male and female siblings caused by a novel mutation and the physiological role of estrogens. J Clin Endocrinol Metab (1995) 80:3689-98. doi:10.1210/jcem.80.12.8530621

92. Mauvais-Jarvis F. Estrogen and androgen receptors: regulators of fuel homeostasis and emerging targets for diabetes and obesity. Trends Endocrinol Metab (2011) 22:24-33. doi:10.1016/j.tem.2010.10.002

93. Matute ML, Kalkhoff RK. Sex steroid influence on hepatic gluconeogenesis and glucogen formation. Endocrinology (1973) 92:762-8. doi:10.1210/endo-92-3762

94. Campbell SE, Febbraio MA. Effect of the ovarian hormones on GLUT4 expression and contraction-stimulated glucose uptake. Am J Physiol Endocrinol Metab (2002) 282:E1139-46. doi:10.1152/ajpendo.00184.2001

95. Hatta H, Atomi Y, Shinohara S, Yamamoto Y, Yamada S. The effects of ovarian hormones on glucose and fatty acid oxidation during exercise in female ovariectomized rats. Horm Metab Res (1988) 20:609-11. doi:10.1055/s-2007-1010897

96. Campbell SE, Febbraio MA. Effect of ovarian hormones on mitochondrial enzyme activity in the fat oxidation pathway of skeletal muscle. Am J Physiol Endocrinol Metab (2001) 281:E803-8.

97. Campbell SE, Angus DJ, Febbraio MA. Glucose kinetics and exercise performance during phases of the menstrual cycle: effect of glucose ingestion. Am J Physiol Endocrinol Metab (2001) 281:E817-25.

98. D'Eon TM, Sharoff C, Chipkin SR, Grow D, Ruby BC, Braun B. Regulation of exercise carbohydrate metabolism by estrogen and progesterone in women. Am J Physiol Endocrinol Metab (2002) 283:E1046-55. doi:10.1152/ajpendo.00271. 2002

99. Ding EL, Song Y, Malik VS, Liu S. Sex differences of endogenous sex hormones and risk of type 2 diabetes: a systematic review and meta-analysis. JAMA (2006) 295:1288-99. doi:10.1001/jama.295.11.1288

100. Turgeon JL, Carr MC, Maki PM, Mendelsohn ME, Wise PM. Complex actions of sex steroids in adipose tissue, the cardiovascular system, and brain: insights from basic science and clinical studies. Endocr Rev (2006) 27:575-605. doi:10.1210/er.2005-0020

101. Selvin E, Feinleib M, Zhang L, Rohrmann S, Rifai N, Nelson WG, et al. Androgens and diabetes in men: results from the Third National Health and Nutrition Examination Survey (NHANES III). Diabetes Care (2007) 30:234-8. doi: $10.2337 / \mathrm{dc} 06-1579$

102. Traish AM, Guay A, Feeley R, Saad F. The dark side of testosterone deficiency: I. Metabolic syndrome and erectile dysfunction. J Androl (2009) 30:10-22. doi:10.2164/jandrol.108.005215

103. Dhindsa S, Miller MG, McWhirter CL, Mager DE, Ghanim H, Chaudhuri A, et al. Testosterone concentrations in diabetic and nondiabetic obese men. Diabetes Care (2010) 33:1186-92. doi:10.2337/dc09-1649

104. Grossmann M, Gianatti EJ, Zajac JD. Testosterone and type 2 diabetes. Curr Opin Endocrinol Diabetes Obes (2010) 17:247-56. doi:10.1097/MED. 0b013e32833919cf

105. Li C, Ford ES, Li B, Giles WH, Liu S. Association of testosterone and sex hormone-binding globulin with metabolic syndrome and insulin resistance in men. Diabetes Care (2010) 33:1618-24. doi:10.2337/dc09-1788

106. Corbould A. Effects of androgens on insulin action in women: is androgen excess a component of female metabolic syndrome? Diabetes Metab Res Rev (2008) 24:520-32. doi:10.1002/dmrr.872

107. Nedungadi TP, Clegg DJ. Sexual dimorphism in body fat distribution and risk for cardiovascular diseases. J Cardiovasc Transl Res (2009) 2:321-7. doi:10.1007/s12265-009-9101-1 
108. McInnes KJ, Corbould A, Simpson ER, Jones ME. Regulation of adenosine 5',monophosphate-activated protein kinase and lipogenesis by androgens contributes to visceral obesity in an estrogen-deficient state. Endocrinology (2006) 147:5907-13. doi:10.1210/en.2006-0879

109. Moverare-Skrtic S, Venken K, Andersson N, Lindberg MK, Svensson J, Swanson C, et al. Dihydrotestosterone treatment results in obesity and altered lipid metabolism in orchidectomized mice. Obesity (Silver Spring) (2006) 14:662-72. doi:10.1038/oby.2006.75

110. Zitzmann M, Gromoll J, Von Eckardstein A, Nieschlag E. The CAG repeat polymorphism in the androgen receptor gene modulates body fat mass and serum concentrations of leptin and insulin in men. Diabetologia (2003) 46:31-9. doi:10.1007/s00125-002-0980-9

111. Fan W, Yanase T, Nomura M, Okabe T, Goto K, Sato T, et al. Androgen receptor null male mice develop late-onset obesity caused by decreased energy expenditure and lipolytic activity but show normal insulin sensitivity with high adiponectin secretion. Diabetes (2005) 54:1000-8. doi:10.2337/diabetes.54.4. 1000

112. Lin HY, Xu Q, Yeh S, Wang RS, Sparks JD, Chang C. Insulin and leptin resistance with hyperleptinemia in mice lacking androgen receptor. Diabetes (2005) 54:1717-25. doi:10.2337/diabetes.54.6.1717

113. Katznelson L, Finkelstein JS, Schoenfeld DA, Rosenthal DI, Anderson EJ, Klibanski A. Increase in bone density and lean body mass during testosterone administration in men with acquired hypogonadism. J Clin Endocrinol Metab (1996) 81:4358-65. doi:10.1210/jcem.81.12.8954042

114. Mauras N, Hayes V, Welch S, Rini A, Helgeson K, Dokler M, et al. Testosterone deficiency in young men: marked alterations in whole body protein kinetics, strength, and adiposity. J Clin Endocrinol Metab (1998) 83:1886-92. doi:10.1210/jcem.83.6.4892

115. Singh R, Artaza JN, Taylor WE, Gonzalez-Cadavid NF, Bhasin S. Androgens stimulate myogenic differentiation and inhibit adipogenesis in C3H 10T1/2 pluripotent cells through an androgen receptor-mediated pathway. Endocrinology (2003) 144:5081-8. doi:10.1210/en.2003-0741

116. Pitteloud N, Mootha VK, Dwyer AA, Hardin M, Lee H, Eriksson KF, et al. Relationship between testosterone levels, insulin sensitivity, and mitochondrial function in men. Diabetes Care (2005) 28:1636-42. doi:10.2337/diacare.28. 7.1636

117. Mootha VK, Lindgren CM, Eriksson KF, Subramanian A, Sihag S, Lehar J, et al. PGC-1alpha-responsive genes involved in oxidative phosphorylation are coordinately downregulated in human diabetes. Nat Genet (2003) 34:267-73. doi:10.1038/ng1180

118. Morimoto S, Mendoza-Rodriguez CA, Hiriart M, Larrieta ME, Vital P, Cerbon MA. Protective effect of testosterone on early apoptotic damage induced by streptozotocin in rat pancreas. J Endocrinol (2005) 187:217-24. doi:10.1677/ joe. 1.06357
119. Palomar-Morales M, Morimoto S, Mendoza-Rodriguez CA, Cerbon MA. The protective effect of testosterone on streptozotocin-induced apoptosis in beta cells is sex specific. Pancreas (2010) 39:193-200. doi:10.1097/MPA. 0b013e3181c156d9

120. Ramsey JJ, Laatsch JL, Kemnitz JW. Age and gender differences in body composition, energy expenditure, and glucoregulation of adult rhesus monkeys. $J$ Med Primatol (2000) 29:11-9. doi:10.1034/j.1600-0684.2000.290102.x

121. Kemnitz JW, Gibber JR, Lindsay KA, Eisele SG. Effects of ovarian hormones on eating behaviors, body weight, and glucoregulation in rhesus monkeys. Horm Behav (1989) 23:235-50. doi:10.1016/0018-506X(89)90064-0

122. Eisner JR, Dumesic DA, Kemnitz JW, Abbott DH. Timing of prenatal androgen excess determines differential impairment in insulin secretion and action in adult female rhesus monkeys. J Clin Endocrinol Metab (2000) 85:1206-10. doi:10.1210/jcem.85.3.6453

123. Abbott DH, Bruns CR, Barnett DK, Dunaif A, Goodfriend TL, Dumesic DA, et al. Experimentally induced gestational androgen excess disrupts glucoregulation in rhesus monkey dams and their female offspring. Am J Physiol Endocrinol Metab (2010) 299:E741-51. doi:10.1152/ajpendo.00058.2010

124. Billiar RB, Richardson D, Schwartz R, Posner B, Little B. Effect of chronically elevated androgen or estrogen on the glucose tolerance test and insulin response in female rhesus monkeys. Am J Obstet Gynecol (1987) 157:1297-302. doi:10.1016/S0002-9378(87)80319-8

125. Bruns CM, Baum ST, Colman RJ, Eisner JR, Kemnitz JW, Weindruch R, et al. Insulin resistance and impaired insulin secretion in prenatally androgenized male rhesus monkeys. J Clin Endocrinol Metab (2004) 89:6218-23. doi:10.1210/jc.2004-0918

Conflict of Interest Statement: The authors declare that the research was conducted in the absence of any commercial or financial relationships that could be construed as a potential conflict of interest.

Received: 05 November 2014; paper pending published: 27 November 2014; accepted: 19 December 2014; published online: 19 January 2015.

Citation: Varlamov O, Bethea CL and Roberts CT Jr (2015) Sex-specific differences in lipid and glucose metabolism. Front. Endocrinol. 5:241. doi: 10.3389/fendo.2014.00241 This article was submitted to Diabetes, a section of the journal Frontiers in Endocrinology.

Copyright (C) 2015 Varlamov, Bethea and Roberts. This is an open-access article distributed under the terms of the Creative Commons Attribution License (CC BY). The use, distribution or reproduction in other forums is permitted, provided the original author(s) or licensor are credited and that the original publication in this journal is cited, in accordance with accepted academic practice. No use, distribution or reproduction is permitted which does not comply with these terms. 